\title{
Fisheries monitoring in Babel: fish ethnotaxonomy in a hotspot of common names
}

\author{
Marília Previero ${ }^{1}$, Carolina V. Minte-Vera ${ }^{1}$ and Rodrigo Leão de Moura ${ }^{2}$
}

The lack of a long term, comprehensive and reliable fisheries statistics system is a major impediment to fisheries management in Brazil. Fishing is one of the main activities throughout the country's coast, with predominance of small-scale, artisanal, multigear, and multispecies captures that are landed in a pulverized network of coastal villages. Brazil is also a hotspot of common names, another feature that challenges artisanal fisheries' monitoring. We combined taxonomic and ethnobiological information to support the implementation of an artisanal fisheries' monitoring program under the co-management framework of a Marine Extractive Reserve in Bahia State, Northeastern Brazil. We surveyed 141 fishing landings, recording 86 fish species (43 families) and 52 correspondences 1:1 between local and scientific names. Broad folk categories had an average of 5.1 specific names, with "cação" (shark) being the category with more specific names (24 names to six biological species). With the exception of species that make up the bycatch captured by shrimp trawling, fisherfolks are able to identify commercially important species from both fresh specimens and photos. Common names can be reliably used in fisheries monitoring programs, and their usage facilitates the participation of fisherfolks in surveys based on voluntary or compulsory declarations of captures.

A falta de um sistema compreensivo e confiável de estatísticas pesqueiras em longo prazo é um dos maiores dificultadores da gestão pesqueira no Brasil. A pesca é uma das principais atividades ao longo da costa do país, com predominância de capturas artesanais de pequena escala, envolvendo múltiplas artes e espécies, além de desembarques realizados em uma rede pulverizada de localidades costeiras. O Brasil também possui grande riqueza de nomes comuns, outra característica que complica o monitoramento da pesca artesanal. No presente trabalho, combinamos informações taxonômicas e etnobiológicas para apoiar a implementação de um programa de monitoramento da pesca artesanal recifal e costeira sob o arcabouço de cogestão de uma Reserva Extrativista Marinha no estado da Bahia, Nordeste do Brasil. Foram amostrados 141 desembarques e registradas 86 espécies de peixes (43 famílias), com 52 correspondências 1:1 entre nomes locais e científicos. Categorias de nomes comuns genéricos tiveram uma média de 5,1 nomes específicos locais, com "cação" sendo aquela com mais nomes específicos (24 nomes para seis espécies biológicas). Excetuando-se as espécies capturadas como fauna acompanhante do arrasto-decamarão, observamos que os pescadores são capazes de identificar as espécies comercialmente importantes tanto a partir de espécimes quanto de fotografias. Os nomes comuns podem ser usados com segurança em programas de monitoramento de pescarias de pequena escala, sendo que seu uso facilita a participação dos pescadores em levantamentos baseados em declarações de captura, sejam elas voluntárias ou compulsórias.

Key words: Bahia, Corumbau, Cumuruxatiba, Local Ecological Knowledge, Marine Extractive Reserve.

\section{Introduction}

Fishing is one of the main activities in rivers, reservoirs, and throughout the Brazilian coast, involving more than two million people (Diegues, 2002). Small-scale artisanal fisheries with both commercial and subsistence components are widespread, operating in a pulverized network of landing sites, with multiple gears and targeting a broad array of target species
- a combination of factors that challenges its assessment and monitoring (Vasconcellos et al., 2007). As a consequence, public policies and subsidies are biased towards the betterreported industrial sector (Abdallah \& Sumaila, 2007), and even the general state of the stocks targeted by artisanal fisheries is still poorly known (Okada et al., 2005; Ruffino, 2008). Remarkably though, the total yields from the artisanal sector are higher than those of industrial fisheries, especially

${ }^{1}$ Universidade Estadual de Maringá, Núcleo de Pesquisas em Limnologia, Ictiologia e Aquicultura (Nupelia), Avenida Colombo 5790, Bloco H-90, 87020-900 Maringá, PR, Brazil.mahpreviero@gmail.com (MP)_cminte@nupelia.uem.br(CVMV)

${ }^{2}$ Universidade Federal do Rio de Janeiro, Instituto de Biologia, Av. Carlos Chagas Filho 373, Ilha do Fundão, 21941-902 Rio de Janeiro, RJ, Brazil.moura@biologia.ufrj.br(RLM) 
in the Northeastern coast (Paiva, 1997; IBAMA, 2010; Begossi, 2010).

Artisanal fisheries are associated with specific coastal territories held under a wide range of tenure arrangements (Cordell, 2007), some of which eventually becoming as Extractive Reserves for initiative of traditional populations. Besides particular modes of labour division across households and communities (e.g., Diegues, 1983, 2004), traditional fisheries comprise a relatively high level of fisherfolks' knowledge about the environment and the target species, which is transmitted over generations (Posey, 1987; Silvano \& Valbo-Jørgensen, 2008; Begossi et al., 2011). The identification of resources by names is one of the first steps in the construction and consolidation of Local Ecological Knowledge (LEK) (Wilson et al., 2006), and a major constituent of traditional fishing territories (Farias Júnior, 2010; Vianna Júnior, 2010; Teixeira et al., 2013).

Marine species targeted by fisheries receive different local names along the extensive, diverse and culturally heterogeneous Brazilian coastline. The national average is six common names for each biological species, but there are fish species with over 30 common names, besides higherlevel taxonomic groups that include different families, genera and species that are referred to by a single common name (Freire \& Pauly, 2005), such as in the case of rays ("raia" or "arraia" in Brazilian Portuguese). This variety of common names has resulted in low resolution assessments, as catch statistics are generally recorded only with common names, challenging stock assessments (Vasconcellos et al., 2007) and the reconstruction of time series for several target species (Freire \& Oliveira, 2007). Assessments of species sold as a single category, such as "red snapper" (e.g., Marko et al., 2004), as well as of transboundary fish stocks (e.g., Collette et al., 2011), are also hampered by the variety of regional names.

In a study about fish folk taxonomy in the Atlantic forest and the Amazon, Begossi et al., (2008) found a great correspondence between the classification made by fisherfolks and the scientific names, but such matches may be much more variable along the coast (Freire \& Pauly, 2005). Therefore, in the scope of a larger initiative aiming at the implementation of a fisheries co-management regime in the Marine Extractive Reserve of Corumbau (MERC) (see Moura et al., 2007, 2009; Alves et al., 2012), we developed and tested a protocol to match common and scientific names of fish species exploited by artisanal fisheries, combining taxonomic and ethnobiological information.

The study was carried out in Cumuruxatiba, the largest fishing village in the MERC, from where capture-related (e.g., Capture Per Unit Effort - CPUE) and biological information have been reported only under common names since 2001 (Alves et al., 2012). Given the importance of artisanal fisheries in Brazil, the "ethnotaxonomy impediment" for fisheries monitoring must be disentangled with such small scale assessments, which can also contribute to the consolidation of traditional fishing territories along the coast and in the major rivers, as common names are primary components of LEK and may be highly specific to circumscribed sections of the coast (Freire \& Pauly, 2005).

\section{Material and Methods}

The Marine Extractive Reserve of Corumbau (MERC) is located in the southern coast of Bahia State, Northeastern Brazil, occupying ca. $900 \mathrm{~km}^{2}$ (Fig. 1). In the late 1990's local fisherfolks, led by villagers from Corumbau and other six neighboring localities with strong Indigenous inheritance (Caraíva, Aldeia Barra Velha, Aldeia Bugigão, Veleiro, Cumuruxatiba, and Imbassuaba), claimed the establishment of an Extractive Reserve. Their main objectives included the exclusion of fishing fleets from other municipalities, improvements of life quality and protection of local culture (Moura et al., 2009). MERC is located in the northern extreme of the so-called Abrolhos Bank, a region that encompasses Brazil's first network of Marine Protected Areas (MPA). Although there are several conflicts between local fisherfolks and MPAs in the Abrolhos Bank, fisherfolks from MERC have always had very limited interaction with the no-take MPAs. A more complete analysis of the MPA system and its conflicts is provided by Moura et al. (2013).

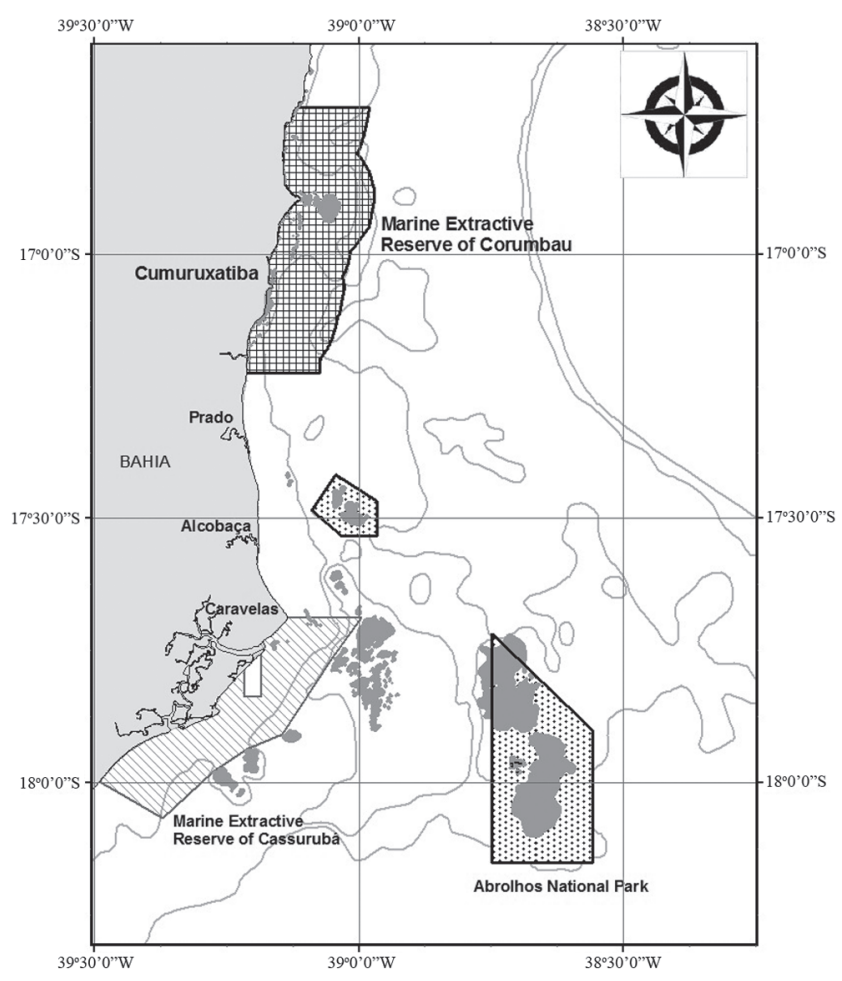

Fig. 1. Map of the study region showing the location of Cumuruxatiba within the Marine Extractive Reserve of Corumbau, Bahia, Northeastern Brazil. 
Our study was conducted in Cumuruxatiba, Prado municipality, the largest MERC village, with an economy based on fishing ( 35 canoes and 25 motor boats) and tourism (Moura et al., 2007; Di Ciommo, 2007). Most traditional fisherfolks from Cumuruxatiba are descendants of Pataxós Indigenous People (the major Pataxós' settlement, Aldeia Barra Velha, is one of the other six coastal villages of the MERC). Cumuruxatiba has one association devoted to communitarian issues, including fisheries, and there is a representative fishing community with 164 families, $45 \%$ of them also involved with tourism (informal employees of hotels and restaurants, housekeepers, trade of food and handicrafts, boat pilots) (Moura et al., 2007, 2009; Di Ciommo, 2007). Cumuruxatiba fisherfolks use hook-and-line, longline, gillnets and spears over reefs, sand, and muddy bottom (Moura et al., 2007), and remain at sea 3-13 days/month and catch $23-186 \mathrm{~kg}$ of fish $/$ month (Alves et al., 2012). The total MERC production for 2006 was estimated at 315-349 t, corresponding to $1 \%$ of the fish production in Bahia State in that year (Alves et al., 2012)

The protocol for matching common and scientific names consisted in a qualitative sampling of 141 landings, followed by interviews with all boat captains and local experts $(n=6)$. Local experts are individuals that were recurrently pointed out as such during 30 initial interviews with randomly selected fisherfolks. Local experts were interviewed about the common names for each of the most frequent names recorded in the fisheries monitoring database. Sampling was carried out intensively for two weeks in 2009, during which most landings were inspected, one week during the summer (February 28 - March 7, 2009) and another during the winter (July 15-22).

At least one specimen of each landed species was collected and had its common name recorded. Specimens were photographed soon after collection, preserved in $10 \%$ formalin and further transferred to $70 \%$ ethanol for identification under stereomicroscope with use of the artificial keys provided by Figueiredo (1977), Figueiredo \& Menezes (1978, 1980, 2000), Menezes \& Figueiredo (1980, 1985), Moura \& Lindeman (2007) and Marceniuk \& Menezes (2007). Vouchers are deposited at the Museu de Zoologia, Universidade de São Paulo (MZUSP) (Table 1). Boat name, fishing spot, gear, and total capture $(\mathrm{kg})$ were also recorded, and a collector's curve was used to assess sampling sufficiency (Krebs, 1989). Richness of common names was further evaluated by counting up synonyms (number of species by common name) and homonyms (number of species associated with each common name) (Minelli, 1999).

In order to assess potential biases arising from the use of photographic catalogs, after six months we re-interviewed 14 of fisherfolks who were interviewed during the summer. In this second interview we showed one to twenty-eight photographs and asked for the common names (number of images was proportional to the amount of fish each fisherfolk captured during the summer).

\section{Results}

The summer survey (92 landings) yielded 67 fish species, while the winter survey (49 fishing landings) yielded 52 fish species, totaling 86 species belonging to 43 families and 12 orders. Twenty species represent new records for the MERC (Table 1). The most species and families were Sciaenidae (15 species), Haemulidae (9), and Carangidae (5) (Fig. 2). The collector's curve began to stabilize after 67 species were sampled in the summer ( 94 landings), but it also reveals that more sampling in the winter could have yielded more species (Fig. 3).

We recorded 102 common names and 52 correspondences (1:1) between scientific and common names (Table 1). Species with the largest variety of common names were caught with trawls (Fig. 4). There were more landings and higher species richness in captures with trawl and hook-and-line, in both seasons (Fig. 5).

Most fish species (67, or 77\%) received a single common name, and most common names ( 74 , or $80 \%$ ) corresponded to only one species (Figs. 6a-b), with a total of 102 common names and an average of 1.5 common names per species (Table 1). Species that received the largest number of common names were Ctenosciaena gracilicirrhus (5 common names), Harengula clupeola (4), Paralonchurus brasiliensis (4) and Bagre marinus (4). Common names with more correspondences to scientific names were "peixe-cascudo" (4 species), "maramassá" (4), and "peixe-branco" (4).

In the interviews with the six local experts, the mean number of specific common names for each generic common name was 5.21. Generic names with more specific names were "cação" (24), "bagre" (11), "raia" (10), "lagosta" (10), and "pescada" (10), while six generic common names ("carapeba", "garoupa", "grassari”, "guaiúba", "salema", and "sauara") had only one name (Table 2).

A total of 89 photos were shown to the fisherfolks that were re-interviewed. Seventy-four percent of the identifications from photographs matched the initial assignments made six months earlier. Mismatches are mostly fishes captured as bycatch of shrimp trawling (e.g., cangatã and bagre-branco; zoiuda and sardinha; miriquita and sardinha) (Fig. 7).

\section{Discussion}

Fishing represents the most important extractive activity in Brazil, with the larger fraction of the National yields coming from the artisanal sector (Vasconcellos et al., 2007; Paiva, 1997; Begossi, 2010). Despite the engagement of more than two million people, legal frameworks and public policies for artisanal fisheries remain weak, resulting in an ever-increasing marginalization of traditional communities, as well as in a steady loss of culturally based Local Ecological Knowledge (Teixeira et al., 2013).

In order to overcome the "ethnotaxonomy impediment" for fisheries monitoring of artisanal fisheries in Brazil, we 
Table 1. Fish species landed in Cumuruxatiba, Bahia, with their corresponding common names and catalog number of vouchers deposited at MZUSP. * First record for the Marine Extractive Reserve of Corumbau.

\begin{tabular}{|c|c|c|c|c|}
\hline Catalog Number & Order & Family & Species & Common names \\
\hline 112178 & Carcharhiniformes & Carcharhinidae & Carcharhinus porosus* & Lauê \\
\hline 112159 & Rajiformes & Dasyatidae & Dasyatis guttata & Raia-cascuda, raia-couro-duro \\
\hline 112149 & & Gymnuridae & Gymnura micrura* & Raia-manteiga, raia-papel \\
\hline 112181 & & Myliobatidae & Aetobatus narinari & Raia-pintada \\
\hline 112137 & & Rhinobatidae & Rhinobatos percellens* & Raia-viola \\
\hline 112194 & Albuliformes & Albulidae & Albula vulpes & Peixe-cutia \\
\hline 112197 & Anguiliformes & Ophichthidae & Ophichthus cylindroideus & Corongo \\
\hline 112161 & Clupeiformes & Clupeidae & Harengula clupeola* & Feijão-queimado, miriquita, sardinha, zoiuda \\
\hline 112147 & & & Odontognathus mucronatus & Peixe-papel, raleza, realeza \\
\hline 112157 & & & Opisthonema oglinum & Sardinha \\
\hline 112138 & & Engraulidae & Anchoa spinifer & Muja \\
\hline 112162 & & & Lycengraulis grossidens & Sardinha, sardinha-boca-de-cancela \\
\hline 112151 & Siluriformes & Ariidae & Bagre bagre & Bagre-vela \\
\hline 112125 & & & Bagre marinus & $\begin{array}{l}\text { Bagre-bagre, bagre-branco, } \\
\text { bagre-cabeçudo, bagre-catinguento }\end{array}$ \\
\hline 112126 & & & Notarius grandicassis* & Bagre-amarelo, caçari, calafate \\
\hline 112190 & Ophidiiformes & Ophidiidae & Ophidion holbrooki & - \\
\hline 112156 & Mugiliformes & Mugilidae & Mugil curema & Tainha \\
\hline 112130 & Scorpaeniformes & Scorpaenidae & Helicolenus dactylopterus* & Mureatinha, pocomã \\
\hline 112128 & & Triglidae & Prionotus punctatus & Peixe-voador, voador \\
\hline 112200 & Perciformes & Carangidae & Caranx latus & Xaréu \\
\hline 112131 & & & Chloroscombrus chrysurus & Xixarro \\
\hline 112140 & & & Oligoplites saurus* & Guaibira \\
\hline 112154 & & & Selene vomer & Galo, peixe-galo \\
\hline 112118 & & & Caranx crysos & Guaricema, xaréu \\
\hline 112191 & & Centropomidae & Centropomus parallelus & Robalo-branco \\
\hline 112139 & & Ephippidae & Chaetodipterus faber & Paru \\
\hline \multirow[t]{2}{*}{112155} & & Gerreidae & Diapterus rhombeus * & Carapeba \\
\hline & & & Eucinostomus gula* & Piratima \\
\hline 112196 & & Haemulidae & Anisotremus surinamensis & - \\
\hline 112133 & & & Anisotremus virginicus & Frade \\
\hline 112188 & & & Boridia grossidens* & Sauara \\
\hline 112158 & & & Conodon nobilis & Curuvina-rajada, giruna \\
\hline 112152 & & & Genyatremus luteus & Sauara \\
\hline 112187 & & & Haemulon aurolineatum & Saquarati \\
\hline 112186 & & & Haemulon parra & Binquara-branca, cain-cain \\
\hline 112170 & & & Haemulon plumierii & Binquara, binquara boca-vermelha \\
\hline 112195 & & & Haemulopsis corvinaeformis & Giruna \\
\hline 112136 & & Labridae & Bodianus rufus & Budião-bico-de-papagaio \\
\hline 112134 & & Lutjanidae & Lutjanus jocu & Ariocó, vermelho \\
\hline 112171 & & & Lutjanus synagris & Ariocó \\
\hline 112119 & & & Ocyurus chrysurus & Cioba, Guaiúba \\
\hline 112169 & & & Rhomboplites aurorubens & Realito \\
\hline 112176 & & Mullidae & Pseudupeneus maculatus & Piau \\
\hline 112168 & & Polynemidae & Polydactylus oligodon * & Barbudo \\
\hline 112175 & & & Polydactylus virginicus & Barbudo \\
\hline 112180 & & Pomacanthidae & Pomacanthus paru & Paru-preto \\
\hline 112203 & & Pomacentridae & Abudefduf saxatilis & Carapiaçava \\
\hline 112184 & & Pomatomidae & Pomatomus saltatrix* & Pixima-do-norte \\
\hline 112202 & & Priacanthidae & $\begin{array}{l}\text { Priacanthus arenatus } \\
\text { Priacanthus } \mathrm{sp} .\end{array}$ & $\begin{array}{c}\text { Olho-de-vidro, zoio-de-vidro } \\
-\end{array}$ \\
\hline 112177 & & Scaridae & Sparisoma axillare & Peixe-batata \\
\hline
\end{tabular}

propose that instead of following the Western trend of standardizing common names (e.g., Nelson et al., 2004), the Brazilian hotspot of common names is comprehensively recorded and understood, and further incorporated in biological surveys and long term monitoring. Such approach would not only improve local participation, but will also help consolidate traditional fishing territories threatened by steadily increasing pressure from industrial fisheries and other sectors. Identification of natural resources by local common names is an important constructive basis of LEK, and a major constituent of traditional fishing territories (Farias Júnior, 2010; Vianna Júnior, 2010).

Our study contributed to characterize the landings and fish ethnospecies' richness in a traditional fishing village in eastern tropical Brazil, but we acknowledge that some of our common name records seem to be generic (i.e., they either refer to rare or poorly-known fishes, or to groups of 
Table 1. cont. Fish species landed in Cumuruxatiba, Bahia, with their corresponding common names and catalog number of vouchers deposited at MZUSP. * First record for the Marine Extractive Reserve of Corumbau.

\begin{tabular}{|c|c|c|c|c|}
\hline Catalog Number & Order & Family & Species & Common names \\
\hline 112165 & & Sciaenidae & Ctenosciaena gracilicirrhus & $\begin{array}{l}\text { Cascudo, joão-torrão, peixe-curuvina, } \\
\text { peixe-branco, peixe-cascudo }\end{array}$ \\
\hline 112167 & & & Cynoscion leiarchus & Enxova, pixima, peixe cascudo \\
\hline 112129 & & & Cynoscion jamaicensis & Cascudo, peixe-branco, peixe-cascudo \\
\hline 112127 & & & Cynoscion virescens & Peixe-branco, pescada \\
\hline 112143 & & & Isopisthus parvipinnis & Peixe-branco \\
\hline 112124 & & & Larimus breviceps & Boca-torta \\
\hline 112148 & & & Macrodon ancylodon & Samucanga \\
\hline 112163 & & & Menticirrhus americanus & Joana, sametara \\
\hline 112140 & & & Menticirrhus littoralis & Joana, sametara \\
\hline 112179 & & & Micropogonias furnieri* & Peixe-curuvina \\
\hline 112183 & & & Nebris microps* & Perna-de-moça \\
\hline 112145 & & & Ophioscion punctatissimus* & Cara-suja \\
\hline 112123 & & & Paralonchurus brasiliensis & $\begin{array}{l}\text { Curuvina-rajada, papaterra, peixe-curuvina, } \\
\text { peixe-rajado }\end{array}$ \\
\hline 112144 & & & Stellifer brasiliensis & Cabeça-de-coco \\
\hline 112189 & & & Stellifer rastrifer & Cabeça-de-coco, peixe-cascudo \\
\hline 112121 & & Scombridae & Euthynnus alletteratus* & Albacora, atum, avacora \\
\hline 112150 & & & Scomberomorus brasiliensis & Avacora, sarda-sarda \\
\hline 112120 & & & Scomberomorus cavalla & Sarda-cavala \\
\hline 112135 & & Serranidae & Cephalopholis fulva & Jabu, catuá, realito \\
\hline 112166 & & & Diplectrum formosum* & Jacundá \\
\hline 112174 & & & Diplectrum radiale & Jacundá \\
\hline 112172 & & Sparidae & Calamus pennatula & Peixe-pena \\
\hline 112160 & & Sphyraenidae & Sphyraena guachancho & Bicuda \\
\hline 112164 & & Stromateidae & Peprilus paru & Pampo-espinho-mole, pampo, capado \\
\hline 112185 & & Trichiuridae & Trichiurus lepturus & Peixe-espada \\
\hline 112199 & & Uranoscopidae & Astroscopus y-graecum* & Pocomã \\
\hline 112198 & Pleuronectiformes & Achiridae & Trinectes paulistanus & Maramassá \\
\hline 112146 & & Cynoglossidae & Symphurus tesselatus & Linguado \\
\hline 112122 & & Paralichthyidae & Cyclopsetta chittendeni & Maramassá \\
\hline 112192 & & & Etropus crossotus* & Maramassá \\
\hline 112142 & & & Syacium papillosum & Maramassá \\
\hline \multirow[t]{2}{*}{112153} & Tetraodontiformes & Balistidae & Balistes capriscus* & Peroá \\
\hline & & Diodontidae & Cyclichthys spinosus & Baiacu, baiacu-de-espinho \\
\hline 112201 & & Monacanthidae & Aluterus monoceros & Peroá-tamanco \\
\hline 112182 & & Tetraodontidae & Lagocephalus laevigatus & Baiacu-ará \\
\hline
\end{tabular}

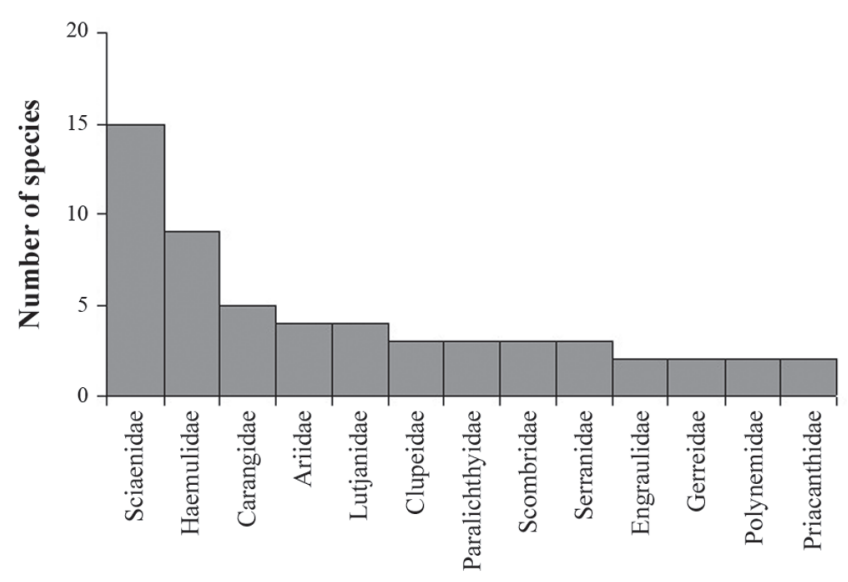

Fig. 2. Number of fish species recorded in each family in the artisanal landings of Cumuruxatiba, Bahia.

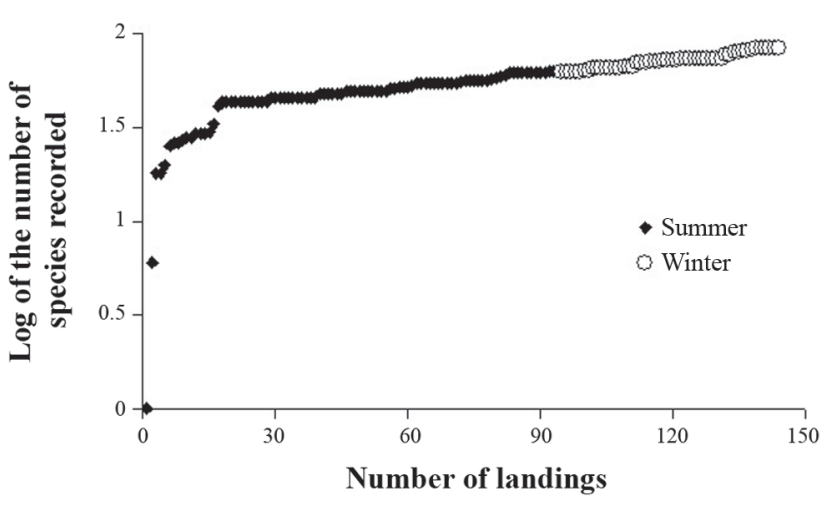

Fig. 3. Collector's curve: cumulative number of species according to the number of landings sampled in Cumuruxatiba, Bahia. 


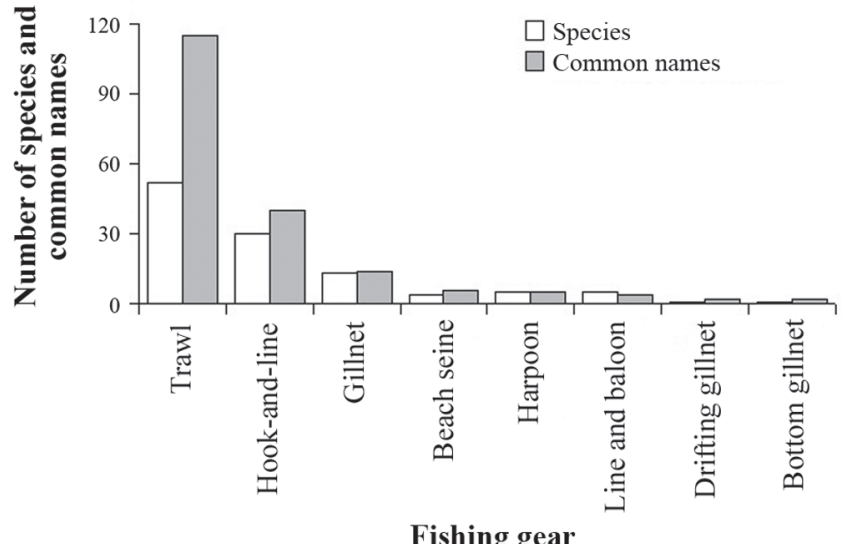

Fig. 4. Richness of common names by species for the main fishing gears utilized in Cumuruxatiba, Bahia.

similar species), and thus might not correspond to ethnospecies (e.g., "peixe-branco"). Although a comprehensive ethnoclassification of the fisheries resources (e.g., Oliveira et al., 2012) was outside the scope of our work, we clearly demonstrate that local names can be reliably used in fisheries monitoring programs, corraborating Begossi et al. (2008) statements and pointing towards a broader application of common names to record fisheries yields, following adequate ethnoichthyology surveys.

We were able to identify 86 fish species and 102 common names, and to match scientific with local names. This study also added 20 species to the previous regional list of $c a$.

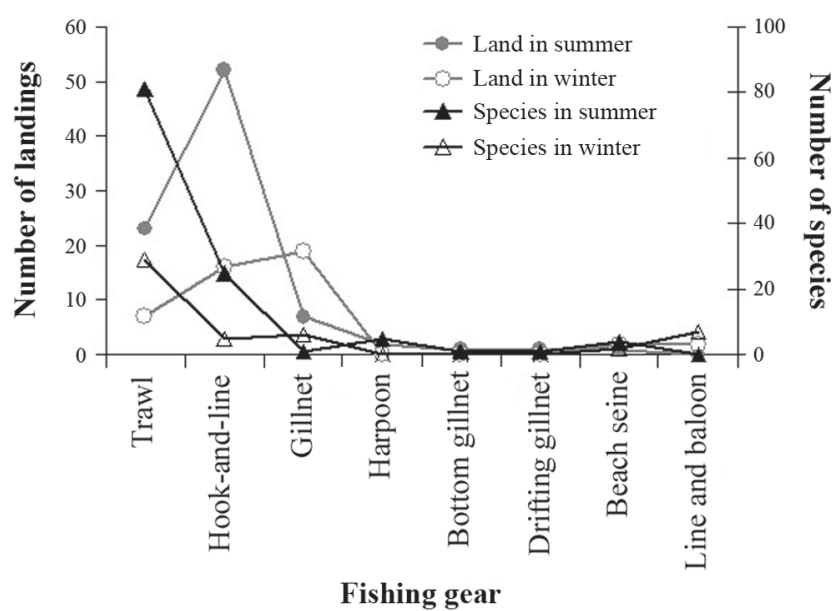

Fig. 5. Number of fish species captured by each fishing gear used by Cumuruxatiba fisherfolks ( $\mathrm{n}=141$ landings).

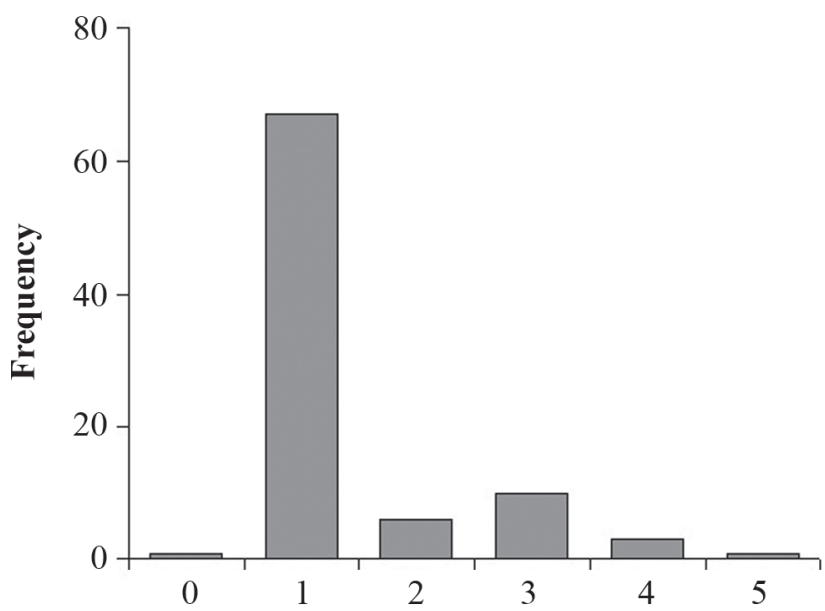

a Number of popular names per species

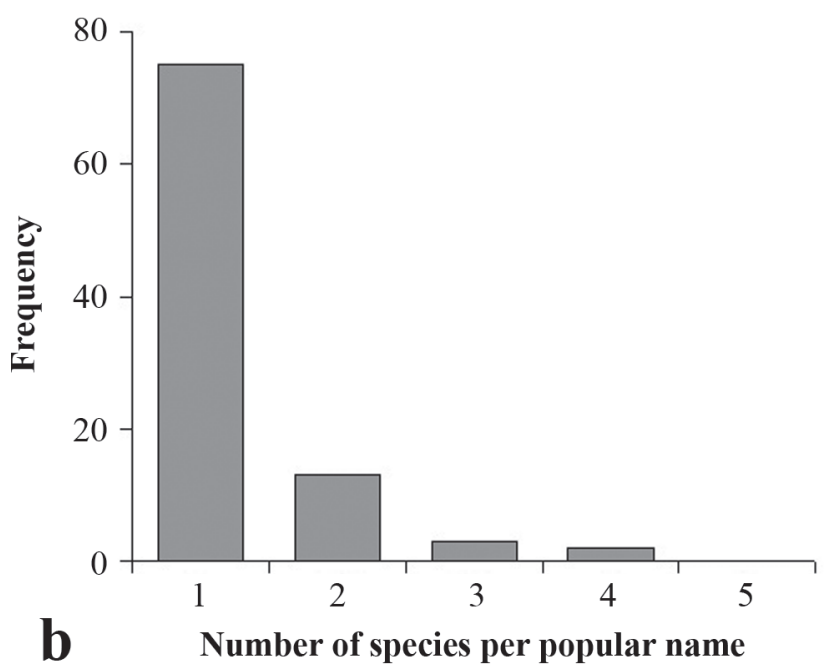

Fig. 6. Richness of common names of marine species in Cumuruxatiba, Bahia. a) frequency of species with 0-5 common names, and b) frequency of common names matching 1-4 species.

270 fish species that includes small, cryptic, and deepdwelling species that are not captured by artisanal fisheries (Moura \& Francini-Filho, 2005). Most commercially important fish species presented only one common name, and local experts indicated relatively few synonyms, much less than the National average of six (Freire \& Pauly, 2005). Throughout the Brazilian coast "cação" (shark) and "pescada" (Sciaenidae - weakfish, croaker) represent 20 and 13 different morphologically similar species, respectively (Freire \& Pauly, 2005). In Cumuruxatiba, we found the same order of magnitude of variation among the local experts that we interviewed, who were able to distinguish 24 different types of "cação" and 10 types of 


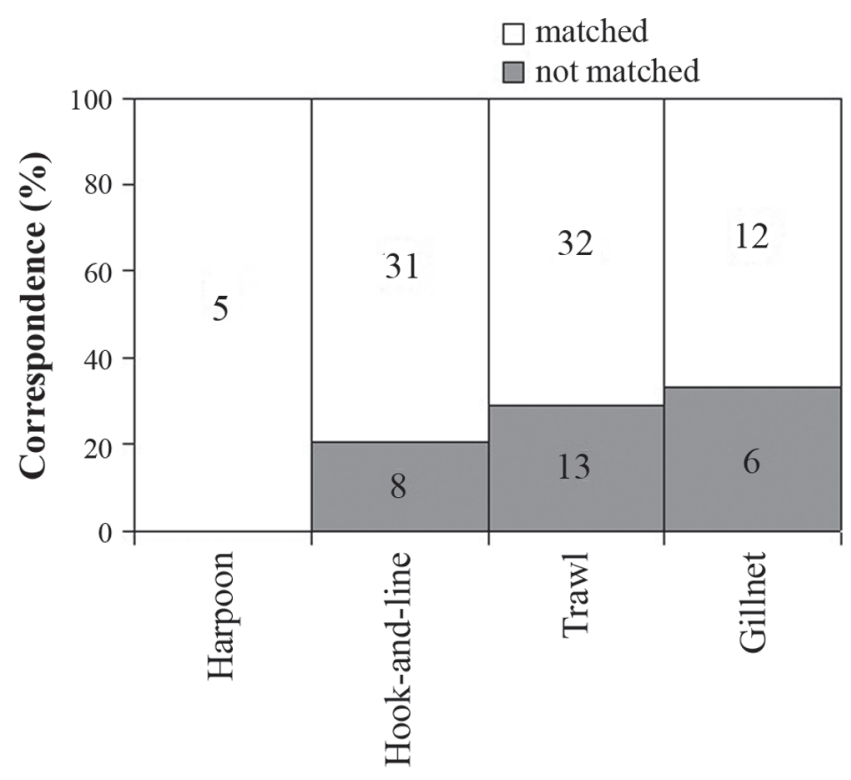

Fishing gear

Fig. 7. Correspondence between the 89 names given by 14 Cumuruxatiba fishers to fresh specimen photographs' shown six months later. Numbers represent the number of species. weakfish ("pescada"). This richness of binomial common names can be applied to statistical fishing data, increasing the accuracy when registering common generic and specific names. From our results, we were able to highlight some pervasive biases in the official statistics, which are based only on common generic names. For instance, landings of 5,240 tonnes of "peroá" were recorded in 2010 (IBAMA, 2012), but throughout the Brazilian coast there are several species that can receive this same name. Only in the MERC area we recorded at least five specific common names for "peroá" (Table 2).

Although Silvano et al. (2006) propose that the LEK about migration and spawning seasons of several coastal fish species is loosely defined in the Northeastern Brazilian coast, the seasonal variation in the occurrence of some species is well perceived among Cumuruxatiba fisherfolks, and was a remarkable characteristic recorded in several opportunities during our fieldwork. For instance, the lower richness of fishes in the winter is a well-recognized pattern across the entire MERC area ("in the winter fish go away to the reefs, and we cannot catch them" - local fisherfolks quote). Begossi et al. (2011) argue that in a neighboring municipality (Porto Seguro, Bahia State), LEK about snappers' reproductive behavior is restricted to older and more experienced fisherfolks. Our results

Table 2. Specific common names for each generic common name mentioned in interviews with local experts fisherfolks from Cumuruxatiba, Bahia. Numbers within parentheses correspond to the number of fisherfolks who cited such specific common name.

\begin{tabular}{|c|c|}
\hline Generic Names & Specific Names \\
\hline Cação & $\begin{array}{l}\text { Cação-baleia (1), c.-barriga-branca (1), c.-buchechudo (1), c.-caneta (1), caciripora (1), galha-preta (2), espadarte (3), c.-ferro (4), c.- } \\
\text { costa-verde (1), lauê-morisco (3), lauê (1), c.- lixa (5), c.- verde (2), c.- viola (2), c.- martelo (2), c.- mourisco (1), panã (1), c.-peru (3), } \\
\text { c.-pintado (1), c.-sombreiro (1), tubarão (1), c.-tintureiro (1), c.-veiad'água (2), lauezinho (1). }\end{array}$ \\
\hline Bagre & $\begin{array}{l}\text { Bagre-amarelo (7), b.-azul (3), bagre (1), b.-branco (4), b.-bravo (1), b.-cabeçudo (4), b.-caçari (3), calafate (3), b.- cangatã (3), b- do- } \\
\text { mangue (1), griamã (2) }\end{array}$ \\
\hline Raia & $\begin{array}{l}\text { Raia-cachorro (1), r.-couro-duro (3), r.-cascuda (3), r.-carimbo (1), r.-jamanta (1), r.-manteiga (6), r.-morcego (2), r.- pintada (3), r.- } \\
\text { roxa (3), r.-jamanta (1) }\end{array}$ \\
\hline Lagosta & $\begin{array}{l}\text { Lagosta- amarela (2), 1.- branca (2), 1.- cabeçuda (1), lagosta (1), 1.- preta (4), 1.- rosada (1), 1.- sapateira (4), 1.- tucano (2), 1.- verde (2), } \\
\text { 1.- vermelha (4) }\end{array}$ \\
\hline Pescada & $\begin{array}{l}\text { Pescada-bicuda (1), escamuda (3), olhuda (3), pescada (2), pescada-amarela (2), pescada-branca (2), pescadinha (4), pixima (2), } \\
\text { pixima-do-norte (1), samucanga (1) }\end{array}$ \\
\hline Badejo & Badejo (6), garoupa (1), peixe-gato (1), b.-preto (1), mero (1), b.-pintado (1), mero-gato (1) \\
\hline Robalo & Robalo-bapeba (1), r.-boca-redonda (1), r.-branco (5), r.-caramurupinho (1), r.-furão (5) \\
\hline Baiacu & Baiacu-ará (5), b.-de-espinho (5), b.-de-rio (1), b.-pinima (2), b.-pintado (1), b.-tingo (1), b.-verde (1) \\
\hline Tubarão & Cabeça-chata (1), costa-de-quina (1), galha-preta (1), panã (1), peru (1), tintureiro (1) \\
\hline Peroá & Peroá-branca (1), p.-chato (1), p.-preto (5), p.-roxo (1), p.-tamanco (2) \\
\hline Sarda & Barracuda (1), sarda-cavala (4), s.-pequena (1), sarda (5), sororoca (1) \\
\hline Binquara & Binquara-amarela (1), b.-boca-vermelha (3), b.-branca (6), b.-preta (3) \\
\hline Peixe pena & Pargo-pena (2), peixe -pena (1), pena (3), rajado (1) \\
\hline Ariocó & Ariocó (6), ariocó-amarelo (1), a.-branco (1) \\
\hline Guaricema & Guaricema-grande (1), guaricema (4), g.-mirim (1) \\
\hline Pescadinha & Pescadinha (1), samucanga (3), pixima (1) \\
\hline Pixima & Pixima-daqui (1), pixima-do-norte (1), pixima (4) \\
\hline Sametara & Sametara-branca (1), sametara (4), s.-suja (1) \\
\hline Xaréu & Cabeçudo (1), grassari (1), xaréu (7) \\
\hline Bonito & Bejupirá (1), bonito (5) \\
\hline Curuvina & Curuvina-grande (1), c.-mirim (1) \\
\hline Samucanga & Pescadinha (1), samucanga (1) \\
\hline Carapeba & Carapeba (1) \\
\hline Garoupa & Garoupa (6) \\
\hline Grassari & Grassari (4) \\
\hline Guaiúba & Guaiúba (5) \\
\hline Salema & Salema (2) \\
\hline Sauara & Sauara (1) \\
\hline
\end{tabular}


are convergent, and we remark that our interviews were directed mainly to local experts who, in general, are the older fisherfolks with more extensive experience. Local Ecological Knowledge has a considerable potential as a reliable, rapid and low cost information source, but it is frequently challenged due to the lack of scientific validation and to the multiple and poorly understood biases deriving from measurement and analytical errors, as well as from political and cultural sources (Teixeira et al., 2013).

Correspondence between ethnospecies and species identified through standard taxonomic methods seems to be greater for fish species captured by hand-line or harpoon. Besides being large-bodied (i.e., easier to identify from morphology - except for sharks) and bearing greater utilitarian value, it seems that the several generation's relationship with these species facilitates their recognition by fisherfolks. On the other hand, shrimp trawling is a relatively new fishing technique, introduced in the late 1970 's in the MERC region, and the recognition of the smaller-sized bycatch fish species that are generally discarded at sea tend to be less accurate. For instance, although MERC fisherfolks had a clear perception of reproductive cycles of lutjanids (snappers) that are traditionally captured with hand-lines (see Freitas et al., 2011), they believed that juvenile penaeid shrimps captured with trawls (mostly Xiphopenaeus kroyeri) were eggbearing carids that are commonly found in shallow warm waters of the study region (authors' unpublished data).

Ethnoecological methods commonly involve showing photographs, maps and drawings to local people, although such two-dimensional and small-size representations may introduce bias in the identifications of species, habitats and behaviors (Begossi et al., 2008; Silvano et al., 2008; Silvano \& Valbø-Jorgensen, 2008). However, we found that the use of photos in interviews with fisherfolks can be reliably used, with few mismatches that generally correspond to smaller species that compose shrimp-trawling bycatch.

Our results emphasized that participatory fisheries monitoring shall start with ethnotaxonomy studies to gather to output reliable species-level data. Aggregation of species under meaningless or standardized (lumped) common names may mask serial depletion, when more valuable and generally less resilient species are overexploited first, followed by the overexploitation of less valuable species with the same generic name (e.g., Kaprov et al., 2000). In this case, only when the whole group is fully depleted (e.g., sharks), landings would decrease. Ecosystem effects of fishing may be assessed using indicators measured in the catches, such as richness and diversity, size of specimens and fisheries capacity (Link, 2010), but these are dependent on species-level discrimination. Thus, collections of local specimens coupled with databases of common names can substantially improve the catch data to be used in fisheries management, also allowing for direct participation of user groups in the decision-making process.

\section{Acknowledgments}

We thank Cumuruxatiba fisherfolks for sharing their knowledge and donating specimens; Daniele M. Nobre, Ufredes de Matos and Fernanda Januário for assistance in data collection; Isabela B. Curado and Manoela Freire for aiding with the identification of local experts; Manoel David de Souza Júnior for support during fieldwork. This work benefited from funding and support from NUPELIA - UEM (Núcleo de Pesquisas em limnologia, Ictiologia e Aquacultura, Universidade Estadual de Maringá), SISBIOTA Rede Abrolhos (CNPq/CAPES/FAPES), Conservation International, the Marine Extractive Reserve of Corumbau, as well as from CAPES and CNPq grants to CVMV and RLM.

\section{Literature Cited}

Abdallah, P. \& U. R. Sumaila. 2007. An historical account of Brazilian public policy on fisheries subsidies. Marine Policy, 31: 44-450.

Alves, D. C., R. L. Moura \& C. V. Minte-Vera. 2012. Estimativa da captura total: desenhos amostrais para pesca artesanal. Interciencia, 37: 899-905.

Begossi, A. 2010. Small-scale fisheries in Latin America: management models and challenges. MAST 9: 5-12.

Begossi, A., M. Clauzet, J. L. Figueiredo, L. Garuana, R. V. Lima, P. F. Maccord, M. Ramires, A. L. Silva \& R. A. M. Silvano. 2008. Are biological species and higher-ranking categories real? Fish folk taxonomy on Brazil's Atlantic forest coast and in the Amazon. Current Anthropology, 49: 291-306.

Begossi, A., S. V. Salivonchyk, L. G. Araujo, T. B. Andreoli, M. Clauzet, C. M. Martinelli, A. G. L. Ferreira, L. E. C. Oliveira \& R. A. M. Silvano. 2011. Ethnobiology of snappers (Lutjanidae): target species and suggestions for management. Journal of Ethnobiology and Ethnomedicine, 7: 1746-4269.

Collette, B. B., K. E. Carpenter, B. A. Polidoro, M. J. Juan-Jorda, A. Boustany, D. J. Die, C. Elfes, W. Fox, J. Graves, L. R. Harrison, R. Mcmanus, C. V. Minte-Vera, R. Nelson, V. Restrepo, J. Schratwieser, C. L. Sun, A. Amorim, M. B. Peres, C. Canales, G. Cardenas, S. K. Chang, W. C. Chiang, N. de Oliveira Leite, H. Harwell, R. Lessa, F. L. Fredou, H. A. Oxenford, R. Serra, K. T. Shao, R. Sumaila, S. P. Wang, R. Watson \& E. Yanez. 2011. High value and long life-Double Jeopardy for tunas and billfishes. Science, 333: 291-292.

Cordell, J. 2007. Marginalidade social e apropriação territorial marítima na Bahia. Pp. 253-263. In: A. L. Costa (Ed.). Nas redes da pesca artesanal. Brasília, Programa das Nações Unidas para o Desenvolvimento, PNUD.

DiCiommo, R. C. 2007. Gender, tourism, and participatory appraisals at the Corumbau Marine Extractive Reserve. Brazil Human Ecology Review, 14: 56-67.

Diegues, A. C. 1983. Pescadores, Camponeses e Trabalhadores do Mar. São Paulo, Ática: Ensaios.

Diegues, A. C. 2002. Povos e águas: inventário das áreas úmidas. São Paulo, Núcleo de Apoio à Pesquisa sobre Populações Humanas e Áreas Úmidas Brasileiras, Universidade de São Paulo.

Diegues, A. C. 2004. A pesca construindo sociedades: leituras em antropologia marítima e pesqueira. São Paulo, Núcleo de Apoio 
à Pesquisa sobre Populações Humanas e Áreas Úmidas Brasileiras, Universidade de São Paulo.

Farias Júnior, E. A. 2010. Cartografia social e conhecimentos tradicionais associados à reivindicação de territorialidades específicas no baixo rio Negro: os quilombolas do tambor. Pp. 90-97. In: Almeida, A. W. B. Cadernos de debates nova cartografia social: conhecimentos tradicionais na Pan-Amazônia. Manaus: Projeto Nova Cartografia Social da Amazônia. UEA Edições.

Figueiredo, J. L. 1977. Manual de peixes marinhos do sudeste do Brasil - I Introdução. Cações, raias e quimeras. São Paulo, Museu de Zoologia da Universidade de São Paulo.

Figueiredo, J. L. \& N. A. Menezes. 1978. Manual de peixes marinhos do sudeste do Brasil - II Teleostei (1). São Paulo, Museu de Zoologia da Universidade de São Paulo.

Figueiredo, J. L. \& N. A. Menezes. 1980. Manual de peixes marinhos do sudeste do Brasil - II Teleostei (2). São Paulo, Museu de Zoologia da Universidade de São Paulo.

Figueiredo, J. L. \& N. A Menezes. 2000. Manual de peixes marinhos do sudeste do Brasil - II Teleostei (5). São Paulo, Museu de Zoologia da Universidade de São Paulo.

Freire, K. M. F. \& T. L. S. Oliveira. 2007. Reconstructing catches of marine commercial fisheries for Brazil. Pp. 61-68. In: Zeller, D. \& D. Pauly (Eds.). Reconstruction of marine fisheries catches for key countries and regions (1950-2005). Vancouver, Fisheries Centre Research Reports.

Freire, K. M. F. \& D. Pauly. 2005. Richness of common names of Brazilian marine fishes and its effect on catch statistics. Journal of Ethnobiology, 25: 279-296.

Freitas, M. O., R. L. Moura, R. B. Francini Filho \& C. V. MinteVera. 2011. Spawning patterns of commercially important reef fish (Lutjanidae and Serranidae) in the tropical western South Atlantic. Scientia Marina, 75:135-146.

IBAMA. 2010. Boletim estatístico da pesca e aquicultura - 20082009. Ministério da Pesca e Aquicultura. Brasília.

IBAMA. 2012. Boletim estatístico da pesca e aquicultura - 2010. Ministério da Pesca e Aquicultura. Brasília.

Kaprov. K. A., P. L. Haaker, I. K. Taniguchi \& L. Rogers-Bennett. 2000. Serial depletion and the collapse of the California abalone (Haliotis spp.) fishery. Canadian Special Publication of Fisheries and Aquatic Sciences, 130: 11-24.

Krebs, C. J. 1989. Ecological methodology. New York, Harper \& Row.

Link, J. S. 2010. Ecosystem-Based Fisheries Management: confronting tradeoffs. New York, Cambridge University Press.

Marceniuk, A. P. \& N. A. Menezes. 2007. Systematics of the family Ariidae (Ostariophysi, Siluriformes), with a redefinition of the genera. Zootaxa, 1416: 1-126.

Marko, P. B., S. C. Lee, A. M. Rice, J. M. Gramling, T. M. Fitzhenry, J. S. McAlister, G. R. Harper, A. L. Moran. 2004. Mislabelling of a depleted reef fish. Nature, 430: 309-310.

Menezes, N. A. \& J. L. Figueiredo. 1980. Manual de peixes marinhos do sudeste do Brasil - II Teleostei (3). São Paulo, Museu de Zoologia da Universidade de São Paulo.

Menezes, N. A. \& J. L. Figueiredo. 1985. Manual de peixes marinhos do sudeste do Brasil - II Teleostei (4). São Paulo, Museu de Zoologia da Universidade de São Paulo.

Minelli, A. 1999. The names of animals. Trends in Ecology and Evolution, 14: 462-463.

Moura, R. L., G. F. Dutra, R. B. Francini-Filho, C. V. Minte-Vera, I. B. Curado, F. J. Guimarães, R. F. Oliveira, D. C. Alves. 2007. Gestão do uso de recursos pesqueiros na Reserva Extrativista Marinha do Corumbau, Bahia. Pp.169-181. In: Prates, A. P. \&
D. Blanc (Eds.). Áreas aquáticas protegidas como instrumento de gestão pesqueira. Brasília, Ministério do Meio Ambiente, Secretaria de Biodiversidade e Florestas.

Moura, R. L. \& R. B. Francini-Filho. 2005. Reef and shore fishes of the Abrolhos Region, Brazil. Pp. 40-55. In: Dutra, G. F., G. R. Allen, T. Werner \& A. S. Mckenna (Eds.). A Rapid marine biodiversity assessment of the Abrolhos Bank, Bahia, Brazil. RAP Bulletin of Biological Assessment 38. Washington, Conservation International.

Moura, R. L. \& K. C. Lindeman. 2007. A new species of snapper (Perciformes: Lutjanidae) from Brazil, with comments on the distribution of Lutjanus griseus and L. apodus. Zootaxa, 1422: 31-43.

Moura, R. L., C. V. Minte-vera, I. B. Curado, R. B. Francini-Filho, H. C. L. Rodrigues, G. F. Dutra, D. C. Alves \& F. J. B. Souto. 2009. Challenges and prospects of fisheries co-management under a Marine Extractive Reserve framework in Northeastern Brazil. Coastal Management, 37: 617-632.

Moura, R. L., N. A. Secchin, G. M. Amado-Filho, R. B. FranciniFilho, M. O. Freitas, C. V. Minte-Vera, J. B. Teixeira, F. L. Thompson, G. F. Dutra, P. Y. G. Sumida, A. Z. Guth, R. M. Lopes \& A. C. Bastos. 2013. Spatial patterns of benthic megahabitats and conservation planning in the Abrolhos Bank. Continental Shelf Research 60 (in press).

Nelson, J. S., E. J. Crossman, H. Espinosa-Pérez, L. T. Findley, C. R. Gilbert, R. N. Lea \& J. D. Williams. 2004. Common and scientific names of fishes from the United States Canada and México. Bethesda, Maryland, American Fisheries Society Publication.

Okada, E. K., A. A. Agostinho \& L. C. Gomes. 2005. Spatial and temporal gradients in artisanal fisheries of a large Neotropical reservoir, the Itaipu Reservoir, Brazil. Canadian Journal of Fisheries and Aquatic Sciences, 62: 714-724.

Oliveira, L. E. C., T. Barreto \& A. Begossi. 2012. Prototypes and folk taxonomy: artisanal fishers and snappers on the Brazilian Coast. Current Anthropology, 53:789-798.

Paiva, M. P. 1997. Recursos pesqueiros estuarinos e marinhos do Brasil. Fortaleza: Edições UFC.

Posey, D. A. 1987. Etnobiologia, teoria e pratica. Pp. 15-25. In: Ribeiro, D. (Ed.). Suma Etnológica Brasileira. Petrópolis, Vozes/ Finep.

Ruffino, M. L. 2008. Sistema integrado de estatística pesqueira para a Amazônia. Pan-American Journal of Aquatic Sciences, 3: 193-204.

Silvano, R. A. M., P. F. L. MacCord, R. V. Lima \& A. Begossi. 2006. When does this fish spawn? Fishermen's local knowledge of migration and reproduction of Brazilian coastal fishes. Environmental Biology of Fishes, 76: 371-386.

Silvano, R. A. M., A. L. Silva, M. Ceroni \& A. Begossi. 2008. Contributions of ethnobiology to the conservation of tropical rivers and streams. Aquatic Conservation: Marine and Freshwater Ecosystems, 18: 241-260.

Silvano, R. A. M. \& J. Valbo-Jørgensen. 2008. Beyond shermen's tales: contributions of shers' local ecological knowledge to sh ecology and sheries management. Environment, Development and Sustainability, 10: 657-675.

Teixeira, J. B., A. S. Martins, H. T. Pinheiro, N. A. Secchin, R. L. Moura \& A. C. Bastos. 2013. Traditional Ecological Knowledge and the mapping of benthic marine habitats. Journal of Environmental Management, 115: 241-250.

Vasconcellos, M., A. C. Diegues \& R. R. Sales. 2007. Limites e possibilidades na gestão da pesca artesanal costeira. Pp. 15-63. 
In: A. L. Costa. Nas redes da pesca artesanal. Brasília, Programa das Nações Unidas para o Desenvolvimento, PNUD.

Vianna Júnior, A. 2010. Terra, territórios e conhecimento tradicional espacial. Pp. 111-116. In: Almeida, A. W. B. Cadernos de debates nova cartografia social: conhecimentos tradicionais na PanAmazônia. Manaus: Projeto Nova Cartografia Social da Amazônia. UEA Edições.

Wilson D. C., J. E. Raakjaer \& P. Degnbol. 2006. Local ecological knowledge and practical fisheries management in the tropics: A policy brief. Marine Policy, 30: 794-801.

Submitted November 5, 2012

Accepted May 12, 2013 by Francisco G. Araujo Published June 28, 2013 